\title{
Watershed-Scale Comparisons of Algal Biodiversity in High-Quality Proximate Hawaiian Stream Ecosystems ${ }^{1}$
}

\author{
Alison R. Sherwood ${ }^{2}$ and Michael H. Kido ${ }^{3}$
}

\begin{abstract}
The stream macroalgal floras of two proximate, high-quality stream valleys (Hanakāpīai and Limahuli) located on the northern quadrant of the Hawaiian island of Kaua' $i$ were inventoried and compared on a watershed scale, providing interesting insight into Hawai'i's potential taxonomic diversity and the influential role played by physical factors in shaping community characteristics. A total of 26 species of macroalgae (five Cyanophyta, 18 Chlorophyta, one Rhodophyta, and two Chromophyta) was identified, of which only eight were common to both streams. Chlorophyta composed the majority of macroalgal taxa identified (63.2\% in Hanakāpí'ai Stream and 66.7\% in Limahuli Stream). Three macroalgal species are new records for Hawai'i and one (Chamaesiphon curvatus var. elongatum Nordst.) is a Hawaiian endemic. Significant differences in the macroalgal densities between Hanakāpīai and Limahuli Streams (Chlorophyta versus Chromophyta, respectively) were attributed to measured differences in riparian canopy cover (34.8\% versus $70.0 \%$ closed, respectively). Significantly lower densities of macroalgal species in riffle-run habitats in Hanakāpīai as compared with Limahuli Stream were potentially explainable by "top-down" control by robust populations of native herbivorous fish species.
\end{abstract}

The stream macroalgae of Hawaici are poorly studied, yet they play a key ecological role as the dominant autotrophic component supporting stream food webs (Kido 1997a). Cladophora sp. (Chlorophyta) and various blue-green algae (Cyanophyta), for example, were found to be primary foods of the native gobiid fishes (Perciformes: Gobioidei: Gobiidae) Awaous guamensis Valenciennes and Sicyopterus stimpsoni Gill, respectively, which

1 This research was supported by the Hawai'i Division of Aquatic Resources (Hawai'i Department of Land and Natural Resources), Limahuli Garden (The National Tropical Botanical Garden), and the Natural Sciences and Engineering Research Council of Canada (NSERC). Manuscript accepted 28 January 2002.

2 Department of Botany, 3190 Maile Way, University of Hawai'i at Mānoa, Honolulu, Hawai'i 96822 (E-mail: asherwoo@hawaii.edu).

${ }^{3}$ The Hawai'i Stream Research Center-Center for Conservation Research and Training, 7370A Kuamo'o Road, Kapa'a, Hawai'i 96746 (E-mail: mkido@hawaii. edu).

Pacific Science (2002), vol. 56, no. 4:431-440

(C) 2002 by University of Hawai'i Press

All rights reserved were used in a mutually exclusive manner with other algal species, depending upon availability (Kido 1997b). Many native aquatic insects utilize algae for food and habitat (Williams 1939, Hardy 1960), some of which are fed upon by native stream fishes (Kido et al. 1993). Similarly, the endemic Hawaiian shrimp Atya bisulcata Randall, found in the higher mountainous reaches of Hawai'i's streams, also feeds on macroalgae (Couret 1976), providing additional evidence of the trophic role of macroalgae in linking native fish and invertebrate components of Hawaiian stream food webs. Despite their ecological importance, however, macroalgae in Hawaiian streams have been understudied, and thus only limited taxonomic information is available to assess the breadth of species diversity and levels of endemicity in the Hawaiian freshwater algal flora.

Vis et al. (1994) conducted the most recent taxonomic study on Hawaiian freshwater macroalgae, surveying spot locations in 29 different streams on the main islands of Kaua'i, O'ahu, Maui, and Hawai'i. Despite the preliminary nature of their study, 34 species of algae were found, of which 25 
(74\%) were new records for Hawaili, and one new species of red alga was described (Batrachospermum spermatiophorum Vis \& Sheath). Several dozen reports over the last century have listed freshwater and terrestrial algal taxa from Hawai'i (e.g., Tilden 1901, MacCaughey 1918a,b, Hustedt 1942). A total of approximately 750 subgeneric freshwater macroalgae (species, varieties, and forms) from seven separate algal lineages have been reported from Hawaici, 52 of which $(6.8 \%)$ have been described from and appear to be endemic to the Hawaiian Islands. This is a relatively low level in comparison with other Hawaiian taxa, in which endemism can be very high (e.g., $89 \%$ for angiosperms and $99 \%$ for insects [Wagner and Funk 1995]), and thus the potential for the discovery of undescribed species of freshwater macroalgae in Hawaiian streams is likely substantial. There is also a need to reexamine many existing species identifications in the state that may be based on outdated taxonomic systems. Thus, further studies on the freshwater algal flora of Hawai'i are warranted, especially in relatively "pristine" stream systems where the native flora is likely to persist.

In addition to limited taxonomic information, very little is known about macroalgal ecology in Hawaiian streams because taxonomists have seldom collected data on factors affecting distribution between streams and ecoregions related to hydrology, riparian zone characteristics, and spatial variation in levels of benthic abundance. Taxonomic surveys have generally been limited to isolated spot collections in easily accessible areas of stream systems with little attention paid to position along the stream continuum or location of a particular stream in its ecoregion. These data, however, would provide interesting insight into factors influencing macroalgal distribution and diversity on various scales. Because algae are the primary autochthonous energy source for food webs in Hawaiian streams, it is essential to understand their influence on stream ecological structure and function.

The general purpose of this study was to compare the macroalgal floras of two regionally proximate Hawaiian watersheds (Hana- kāpī'ai and Limahuli) along their entire drainages from both a taxonomic and ecological perspective to provide insight into the ecology and biodiversity of macroalgae in Hawai'i. In these two watersheds, the specific objectives of our study were the following: (1) to develop survey methodologies and strategies for conducting watershed-scale, ecologically based macroalgal inventories in Hawai'i's streams; (2) to undertake a detailed watershed-scale taxonomic inventory of the macroalgal flora; (3) to compare levels of algal biomass (densities) within and between proximate streams spatially along the stream continua; and (4) to evaluate the role of selected physical and biological factors in affecting the taxonomic composition and ecological characteristics of the algal flora within and between stream systems.

\section{MATERIALS AND METHODS}

Limahuli and Hanakāpī'ai Streams, located on the northern quadrant of Kaua'i Island (Figure 1), were selected for this study because of their proximate location, relatively natural physical condition, high biological quality, and similar physiognomies. Mapbased comparisons indicated that the two stream systems have a nearly identical slope gradient, dropping quickly from about $625 \mathrm{~m}$ elevation $(2000 \mathrm{ft})$ to the ocean over a distance of less than $6.4 \mathrm{~km}$ (4 miles). Despite these similarities, however, the two stream systems differ in historical levels of humaninduced disturbance, with Hanakāpī'ai Valley being the more "pristine" of the two because it has been historically protected within a regional state park.

In each stream system, three generalized collecting areas were selected along the stream continuum and distinct study sites were established on each stream in these areas at lower (26 m [85 ft]), middle (134 m [440 $\mathrm{ft}]$ ), and upper (305 m [1000 ft]) elevations in the watershed. Study sites were approximately $120 \mathrm{~m}$ long and were sampled on a quarterly basis from September 1998 until August 1999 for mean algal standing biomass, and resampled in the spring of 2001 (February 2001 to May 2001) for macroalgae. 


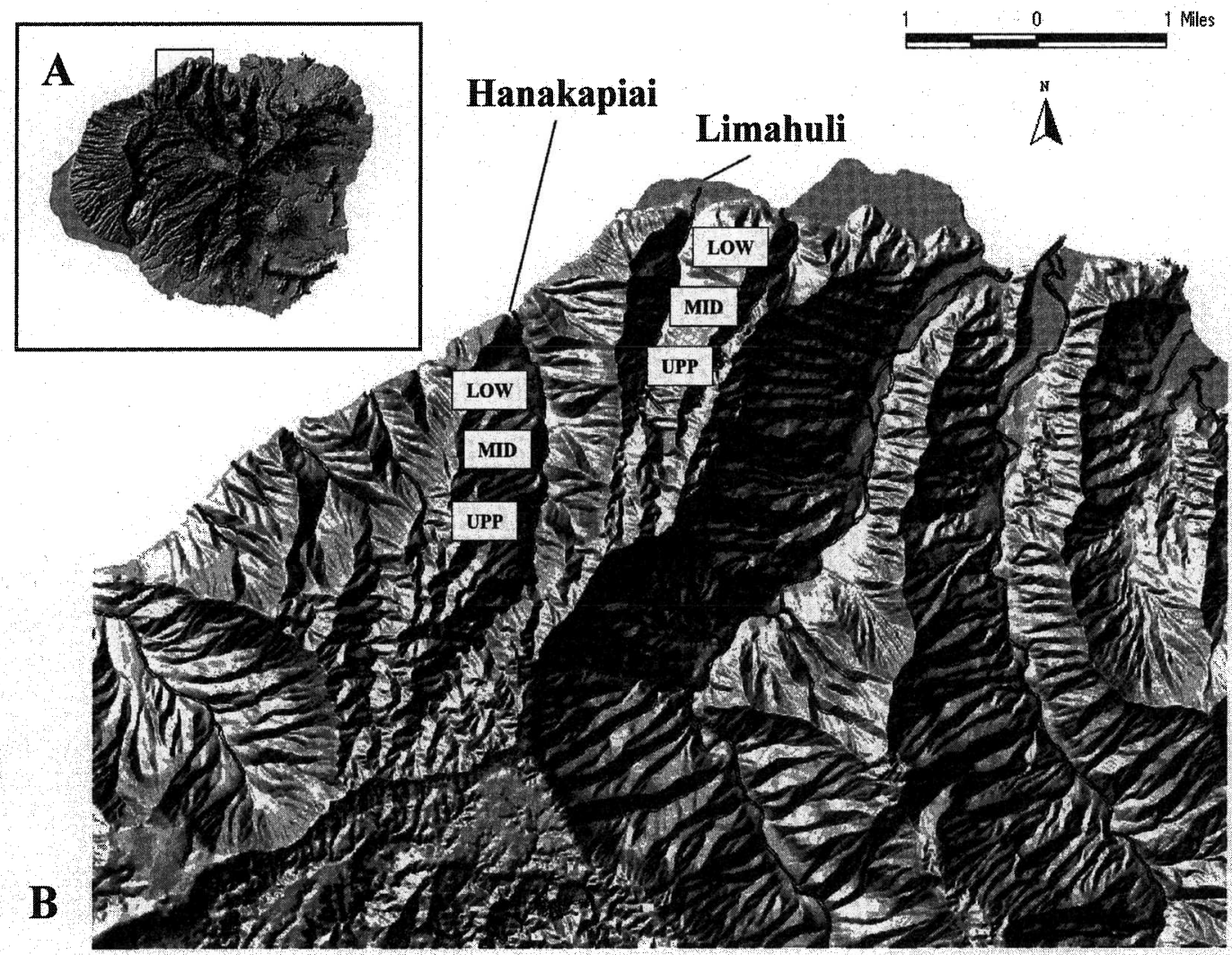

FIGURE 1. $A$. Island of Kaua'i, showing regional location of study streams on northern Kaua'i. B. Proximate location of Hanakāpīai and Limahuli Streams and generalized collecting areas in lower (low), middle (mid), and upper (upp) elevations along the stream continuum.

Relevant stream and riparian habitat attributes in Hanakāpī'ai and Limahuli Streams were compared on a watershed scale. Average riparian canopy coverage at study sites was estimated using densiometer measurements taken at meter intervals along 10 randomly located stream cross-sectional transects. Canopy data were averaged among sites to provide an overall measure of the degree to which the stream continuum was enclosed by riparian trees. Tree species were recorded along transects and their percentage coverages in the riparian canopy estimated. For hydrological comparisons of stream size, mean stream flow was measured at the lower elevation site in each stream (maximal flow volume) (September 1998, February 1999, and June 1999) using a flow meter (Swoffer) and wading rod to measure depth (m) and velocity $\left(\mathrm{m} \cdot \mathrm{sec}^{-1}\right)$ at $0.5-\mathrm{m}$ intervals along a transect anchored bank-to-bank across the stream. Incremental flows measured at each interval were summed to determine mean flow as:

$$
\begin{aligned}
& \text { mean flow }\left(\mathrm{m}^{3} \cdot \sec ^{-1}\right) \\
& \quad=w^{1} D^{1} v^{1}=w^{2} D^{2} v^{2}+\cdots+w^{n} D^{n} v^{n}
\end{aligned}
$$

where $w$ is the interval width $(\mathrm{m}), D$ is the interval depth $(\mathrm{m})$, and $v$ is mean water velocity $\left(\mathrm{m} \cdot \mathrm{sec}^{-1}\right)$ at a point in the water column that is $60 \%$ of $D$.

Stream flow and velocity data were averaged among sites for comparison purposes between proximate streams. Stream temperature was measured at similar times in the lower site only (September 1998, February 1999, and June 1999) using a digital temperature meter (Oakton). 
To evaluate levels of species diversity, macroalgae were collected from all habitats within the generalized collecting areas including waterfalls, riffles, pools, rheocrenes, and at the estuarine region of the marine/ freshwater interface. Macroalgae are defined as benthic algae with a mature thallus that is a discrete structure discernable to the naked eye (Sheath and Cole 1992). Macroalgae were collected wherever sighted within the study area using a glass-bottomed view box and were removed using long-handled forceps. All samples were fixed at the site for light microscopy in $2.5 \% \mathrm{CaCO}_{3}$-buffered glutaraldehyde to prevent morphological distortion (Hambrook and Sheath 1991). In the laboratory, fixed samples were examined using both compound and dissecting microscopes and identified using taxonomic treatments and available papers on both Hawaiian and other worldwide works on algae (e.g., Nordstedt 1876, Collins 1908-1918, Smith 1950, Desikachary 1959, Prescott 1962, Vis et al. 1994). Identifications from the two streams were evaluated for overall macroalgal richness (number of species per stream) and the number of likely endemic taxa. Results were compared with broad-scale biogeographic compilations of stream macroalgal studies in North America (e.g., Sheath and Cole 1992).

To compare overall macroalgal densities, benthic sampling was conducted in three separate wadable riffle-run areas (lowermiddle-upper elevations) in each of the study sites, for all sampling times. In each riffle-run location, algae growing on five randomly located boulder substrata (Cummins 1962) were collected using a Surber-type sampler (Surber 1937). In addition, five randomly located smaller cobble-sized particles (Cummins 1962) were removed, scraped of algae, and processed according to field and laboratory procedures outlined in Kido et al. (1999). Algal densities in samples were determined by placing the material in a single layer in an appropriately sized petri dish and estimating the percentage area covered by individual algal species in a minimum of 10 randomly selected fields of view at low power under a dissecting microscope. When necessary, algae were slide-mounted and identified using a compound microscope. Species percentages were multiplied by ashed sample weights and divided by Surber or rock areas to yield macroalgal densities in $\mathrm{g}$ AFDM (ash free dry mass) $\cdot \mathrm{m}^{-2}$.

Macroalgal density data were normalized with a $\log (x+1)$ transformation, and a oneway analysis of variance (ANOVA) was used in comparisons (GLM procedure [SAS Institute 1989]) to test for mean density differences within and between streams. With significant ANOVA results, means were separated $(P<0.05)$ using the Duncan test (SAS Institute 1989). In all cases only untransformed means were reported. ANOVA was initially used to compare total algal densities among sites, within sites, and between Hanakāpī'ai and Limahuli Streams. Densities were subsequently compared at the division and species levels to evaluate differences in algal composition between streams. Only spatial (not temporal) comparisons were made because quarterly sampling schedules did not provide the resolution required to assess the influence of extreme and unpredictable temporal variation in flow regimes on algal populations. Results from the different sampling times were averaged for each stream.

\section{RESULTS}

\section{Stream Habitat Parameters}

Despite their proximate geographical location, similarities in drainage areas, and overall slope, Hanakāpī'ai Stream and Limahuli Stream were found to differ markedly in certain key physical attributes affecting macroalgal diversity and abundance. For example, Limahuli Stream was determined to be more light limited than Hanakāpīaai Stream because it is much more shaded by riparian trees along the continuum (Table 1). The aggressive alien plant common yellow guava (Psidium guajava L.) was found to be the dominant tree species along both stream continua but to differing degrees $(91.5 \pm$ $4.3 \%$ and $54.7 \pm 4.0 \%$ of riparian canopy species in Hanakāpī'ai and Limahuli Streams, respectively). Hanakāpīaai Stream was also 
TABLE 1

Habitat Attributes of Hanakāpī'ai and Limahuli Streams, Kaua'i

\begin{tabular}{lcc}
\hline \hline Habitat Attribute & Hanakāpīai Stream $^{\circ}$ & Limahuli Stream \\
\hline Riparian canopy cover $^{a}$ & $34.8 \pm 7.4 \%$ & $70.0 \pm 7.6 \%$ \\
Mean water temperature $^{b}$ & $19.6 \pm 0.14^{\circ} \mathrm{C}$ & $19.8 \pm 0.07^{\circ} \mathrm{C}$ \\
& $\left(67.3 \pm 0.27^{\circ} \mathrm{F}\right)$ & $\left(67.6 \pm 0.11^{\circ} \mathrm{F}\right)$ \\
Mean flow (discharge) & $0.36 \pm 0.017 \mathrm{~m}^{3} \cdot \mathrm{sec}^{-1}$ & $0.18 \pm 0.007 \mathrm{~m}^{3} \cdot \mathrm{sec}^{-1}$ \\
\hline
\end{tabular}

${ }^{a}$ Estimates from densiometer measurements.

${ }^{b}$ Averaged for elevational study sites (June 1999).

${ }^{c}$ Measured September 1998, February 1999, and June 1999 at about $26 \mathrm{~m}(85 \mathrm{ft})$ elevation.

found to be larger, having nearly twice the discharge of Limahuli Stream (Table 1). Water temperatures measured in the two stream systems at approximately the same times and locations, however, were determined to be similar (Table 1).

\section{Taxonomic Diversity of Stream Macroalgae}

Systematic collections made of the macroalgae of Limahuli and Hanakāpīai Streams revealed a relatively high taxonomic diversity. A total of 15 macroalgal taxa was identified from Limahuli Stream and 19 taxa from Hanakāpī'ai Stream (Table 2). These numbers were substantially higher than average numbers of taxa per segment reported by Sheath and Cole (1992) in the compiled results of a survey of over 1000 stream segments representing all major biomes in North America (average $3.1 \pm 0.3$, range $0-11$ ), although results of that study were based on 20-m stream segments rather than surveys along the entire stream length.

Green algae, or Chlorophyta, composed the majority of macroalgal taxa identified from both Hanakāpī'ai and Limahuli Streams (63.2 and $66.7 \%$, respectively), followed by blue-green algae, or Cyanophyta (21.1 and $13.3 \%$, respectively); golden algae, or Chromophyta (10.5 and $13.3 \%$, respectively); and red algae, or Rhodophyta (5.3 and $6.7 \%$, respectively) (Figure 2, Table 2). Although the taxonomic composition of the two streams differed somewhat (only eight taxa were common to both streams [30.8\% of total] [Table 2]), the proportions represented by each algal division were very similar (Figure
2). The high representation of green algae may be due in part to the large numbers of algae that can only be identified to the level of species when characteristics pertaining to sexual reproduction are available (e.g., Bulbochaete, Oedogonium, Spirogyra, and Zygnema). Although one collection of Spirogyra was found reproducing sexually ( $S$. rivularis [Hass.] Rabenh.), most of these algae were in an asexual state at the time of collection and are presented as separate entities (e.g., Spirogyra sp. \# 1, Spirogyra sp. \#2) based on vegetative morphological differences. With continued sampling in the two streams it is possible that most of these taxa will eventually be identified to the level of species, and the overall number of taxa may be reduced if it is demonstrated that reproductive characters unite several similar morphological forms.

Three new records for the Hawaiian Islands were included in these collections ( $\mathrm{Ta}$ ble 2): the blue-green alga Schizotbrix rivularis (Wolle) Drouet was identified from Hanakāpi'ai Stream and the green algae Binuclearia tatrana Wittrock and Spirogyra rivularis were identified from Limahuli Stream (see also Sherwood et al. 2002). In addition, the endemic blue-green alga Chamaesiphon curvatus var. elongatum Nordst. was found in Limahuli Stream. This alga was previously known only from the island of O'ahu (Nordstedt 1876, Lemmerman 1905).

\section{Macroalgal Density Comparisons}

Although Chlorophyta dominated both $\mathrm{Ha}-$ nakāpī'ai and Limahuli Streams from a taxonomic perspective, abundances of the 
TABLE 2

Macroalgal Taxa Collected in All Habitats in Hanakāpīaai and Limahuli Streams Study Sites (X Indicates Presence in Study Site)

\begin{tabular}{|c|c|c|c|c|c|c|}
\hline \multirow[b]{2}{*}{ Taxon } & \multicolumn{3}{|c|}{ Hanakāpī'ai Stream } & \multicolumn{3}{|c|}{ Limahuli Stream } \\
\hline & Lower & Middle & Upper & Lower & Middle & Upper \\
\hline \multicolumn{7}{|l|}{ Cyanophyta } \\
\hline Cbamaesiphon curvatus var. elongatum Nordst. & & & & & $\mathrm{X}$ & \\
\hline Leptolyngbya tenuis (Gomont) Anag. \& Komár. & & $\mathrm{X}$ & & & & \\
\hline Nostoc cf. batei Dixit & & $\mathrm{X}$ & $\mathrm{X}$ & & & \\
\hline Pbormidium retzii (C. Ag.) Gomont & & & $\mathrm{X}$ & & $\mathrm{X}$ & \\
\hline Schizotbrix rivularis (Wolle) Drouet & & & $\mathrm{X}$ & & & \\
\hline \multicolumn{7}{|l|}{ Chlorophyta } \\
\hline $\begin{array}{l}\text { Binuclearia tatrana Wittrock } \\
\text { Bulbocbaete sp. }\end{array}$ & & & & & & $\begin{array}{l}X \\
X\end{array}$ \\
\hline $\begin{array}{l}\text { Cladophora glomerata var. glomerata (L.) Kütz. } \\
\text { Cladophora sp. }\end{array}$ & $\mathrm{X}$ & $\mathrm{X}$ & $\begin{array}{l}X \\
X\end{array}$ & $\mathrm{X}$ & $\mathrm{X}$ & $\mathrm{X}$ \\
\hline Cloniophora plumosa (Kütz.) Bourrelly & $\mathrm{X}$ & & & $\mathrm{X}$ & $X$ & $\mathrm{X}$ \\
\hline Cloniophora spicata (Schmid.) emend Islam & $\mathrm{X}$ & & & & & \\
\hline Cloniophora sp. & & $\mathrm{X}$ & & & & \\
\hline Oedogonium sp. \#3 & & $\mathrm{X}$ & $\mathrm{X}$ & & & \\
\hline Oedogonium sp. \#4 & $\mathrm{X}$ & $\mathrm{X}$ & & & & \\
\hline Oedogonium sp. \#5 & & & $\mathrm{X}$ & & & \\
\hline Rbizoclonium bieroglyphicum (C. Ag.) Kütz. & & & $\mathrm{X}$ & & & \\
\hline Spirogyra rivularis (Hass.) Rabenh. & & & & & $\mathrm{X}$ & \\
\hline Spirogyra sp. \#2 & & & & $\mathrm{X}$ & & \\
\hline Spirogyra sp. \#3 & & & & $\mathrm{X}$ & & \\
\hline Spirogyra sp. \#6 & & & $\mathrm{X}$ & & & \\
\hline Spirogyra sp. \#7 & $\mathrm{X}$ & $\mathrm{X}$ & & & & $\mathrm{X}$ \\
\hline Spirogyra sp. \# 8 & $\mathrm{X}$ & $\mathrm{X}$ & $X$ & & & $\mathrm{X}$ \\
\hline Zygnema sp. \#1 & & & & & & $\mathrm{X}$ \\
\hline \multicolumn{7}{|l|}{ Rhodophyta } \\
\hline $\begin{array}{l}\text { Hildenbrandia angolensis Welw. ex G. S. West } \\
\& \text { W. West }\end{array}$ & & & $\mathrm{X}$ & & & $X$ \\
\hline \multicolumn{7}{|l|}{ Chromophyta } \\
\hline Hydrosera whampoensis Schwartz & $\mathrm{X}$ & $\mathrm{X}$ & $\mathrm{X}$ & $\mathrm{X}$ & $\mathrm{X}$ & $\mathrm{X}$ \\
\hline Melosira varians $\mathrm{C} . \mathrm{Ag}$. & & $\mathrm{X}$ & $\mathrm{X}$ & & $\mathrm{X}$ & \\
\hline
\end{tabular}

taxonomic groups differed between streams (densities in $\mathrm{g}$ AFDM $\cdot \mathrm{m}^{-2}$ ). Chlorophyta composed the bulk of macroalgal biomass collected in riffle-run habitat in Hanakāpī'ai Stream $(69.2 \%)$ followed by Cyanophyta and Chromophyta $(23.1$ and $7.7 \%$ of total biomass, respectively) (Figure 2). In Limahuli Stream, the bulk of macroalgal biomass was composed of Chromophyta, Chlorophyta, and Cyanophyta $(68.8,21.8$, and $9.4 \%$ of total biomass, respectively) (Figure 2). Several species of Cladophora and Spirogyra (Chlorophyta) and the diatom Hydrosera whampoensis (Chromophyta) were the dominant macro- algae in the two streams in terms of overall biomass (Table 3).

Macroalgal densities differed significantly between the two streams $(F=8.85$, df $=1$, $P=0.0033)$, with Limahuli Stream (0.12 \pm $0.0279 \mathrm{~g} \mathrm{AFDM} \cdot \mathrm{m}^{-2}$ ) having a significantly higher overall mean density than Hanakāpīai Stream $\quad\left(0.003 \pm 0.0007 \mathrm{~g} \quad \mathrm{AFDM} \cdot \mathrm{m}^{-2}\right)$ $(P<0.05)$. Spirogyra species were found in significantly higher densities $(P<0.05)$ than all other algae in Hanakāpī'ai Stream, and Hydrosera whampoensis was the dominant alga in terms of density $(P<0.05)$ in Limahuli Stream. There was no significant difference 
Taxon Diversity

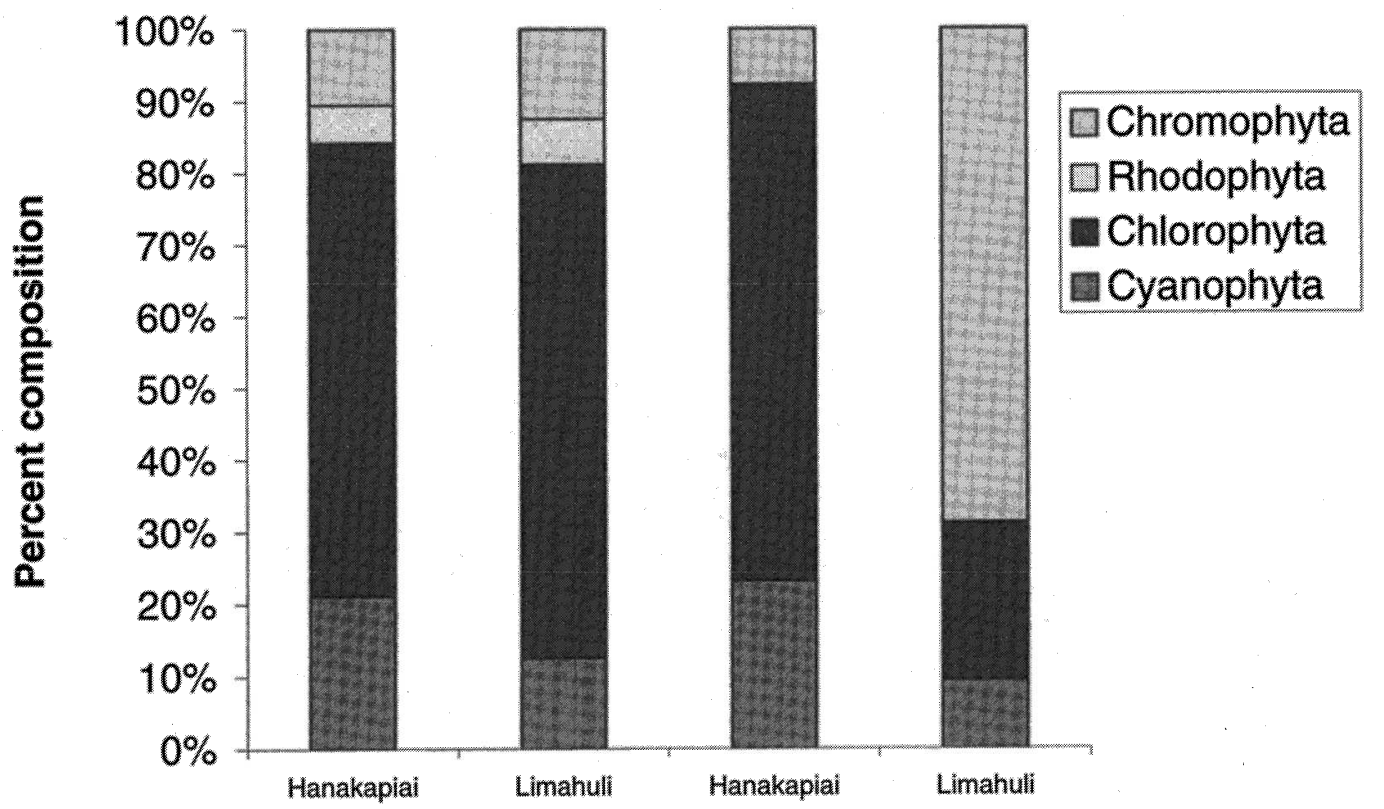

FIGURE 2. Proportions of major macroalgal taxa (Cyanophyta, Chlorophyta, Rhodophyta, and Chromophyta) collected in Hanakāpī'ai and Limahuli Streams in terms of taxonomic diversity and total average biomass.

\section{TABLE 3}

Mean Standing Biomass \pm SE (AFDM $\cdot \mathrm{m}^{-2}$ ) of Macroalgal Species in Hanakāpī'ai and Limahuli Streams, Kaua' $i$, as Determined by Quarterly Standardized Benthic Sampling in Lower, Middle, and Upper Elevational Study Sites from September 1998 to August 1999

\begin{tabular}{lcc}
\hline \hline Taxon & $\begin{array}{c}\text { Hanakāpīai Stream } \\
\left(\mathrm{g} \text { AFDM } \cdot \mathrm{m}^{-2}\right)\end{array}$ & $\begin{array}{c}\text { Limahuli Stream } \\
\left(\mathrm{g} \mathrm{AFDM} \cdot \mathrm{m}^{-2}\right)\end{array}$ \\
\hline Cyanophyta & $0.006 \pm 0.0019$ & $0.056 \pm 0.0194$ \\
Nostoc cf. batei Phormidium retzii & $0.001 \pm 0.0001$ & $0.038 \pm 0.0139$ \\
Mixed species mat & $0.001 \pm 0.0003$ & $0.005 \pm 0.0046$ \\
Chlorophyta & $0.003 \pm 0.0019$ & $\mathrm{NA}$ \\
Cladophora spp. & $0.018 \pm 0.0037$ & $0.130 \pm 0.0383$ \\
Cloniophora spp. & $0.004 \pm 0.0022$ & $0.080 \pm 0.0184$ \\
Oedogonium spp. & $0.001 \pm 0.0004$ & $0.002 \pm 0.0011$ \\
Spirogyra spp. & $0.001 \pm 0.0002$ & $0.013 \pm 0.0077$ \\
Chromophyta & $0.013 \pm 0.0030$ & $0.048 \pm 0.0105$ \\
Hydrosera whampoensis & $0.002 \pm 0.0008$ & $0.410 \pm 0.0790$ \\
Mixed pennate diatoms & $0.001 \pm 0.0008$ & $0.361 \pm 0.0759$ \\
& $0.001 \pm 0.0001$ & $0.048 \pm 0.0144$ \\
\hline
\end{tabular}


in macroalgal densities among sites in Hanakāpī'ai Stream $(F=1.47, \mathrm{df}=2, P=0.2371)$; however, in Limahuli Stream among-site differences were significant $(F=2.77, \mathrm{df}=2$, $P=0.0566$ ), with the middle-elevation site having significantly higher mean macroalgal densities $\left(0.215 \pm 0.0735 \mathrm{~g} \quad \mathrm{AFDM} \cdot \mathrm{m}^{-2}\right)$ than the upper $(0.082 \pm 0.0299 \mathrm{~g}$ AFDM . $\left.\mathrm{m}^{-2}\right)$ and lower $(0.074 \pm 0.0250 \mathrm{~g} \mathrm{AFDM}$. $\left.\mathrm{m}^{-2}\right)$ sites.

\section{DISCUSSION}

The results of this study provide interesting and useful insight into the levels of taxonomic diversity in the macroalgal flora that may potentially be expected from other Hawaiian streams. In addition to this floristic work, we report three new records of stream macroalgae for Hawai'i. Future surveys have the potential to add to the list of recorded macroalgal species from Hawai'i's streams and also the possibility of establishing higher levels of endemicity in the Hawaiian freshwater flora.

Although Chlorophyta dominated both Hanakāpíai and Limahuli Streams in total numbers of taxa, it is interesting to note that the two streams differed significantly in the presence of major taxa when standing macroalgal densities in riffle-run habitats were compared. Hanakāpī'ai Stream, which was open canopied (34.8\% closed) and thus not light limited, had high densities of Chlorophyta (69.2\% of total biomass) as compared with other taxa. In contrast, Chromophyta (68.8\% of total biomass) were the dominant taxa in the neighboring Limahuli Stream, which was severely light limited by riparian canopy $(70.0 \%$ closed). Chlorophyta are known to be less tolerant to low light intensities than Cyanophyta or Chromophyta (Richardson et al. 1983), and thus light limitation imposed by an aggressive riparian canopy appears to have a substantial effect on macroalgal diversity and the corresponding macroalgal biomass in Hawaiian streams. This is supported by previous studies that concluded that algal biomass correlated with the extent of riparian canopy coverage, and that benthic algal production was strongly constrained by the amount of shading in the stream (e.g., Hill and Harvey 1990). Riparian zones along Hawaiian streams, then, likely exercise substantial influence over algal species diversity through regulation of light regimes impacting stream surfaces.

Because of the important role of riparianinduced light limitation, it was initially surprising that overall macroalgal densities were determined to be significantly higher in Limahuli Stream (which was more extensively closed by riparian canopy). It is well established, however, that high levels of grazing pressure by herbivores can eliminate the correlation of algal biomass responses to light (e.g., Hill et al. 1995). We have consistently recorded native herbivorous fish densities in Hanakāpīai Stream at two to three times those measured in Limahuli Stream during several years of sampling (M.H.K., unpubl. data). Macroalgae have not only been shown to be important foods for native stream fishes (e.g., Kido 1997b), but competition for certain species such as Cladophora spp. (Chlorophyta) has been implicated in determining fish community structure in $\mathrm{Ha}$ waiian streams (e.g., Kido 1996). Indeed, it has been suggested that native food webs in Hawaiian streams are structured around and are dependent on macroalgal species (Kido 1996). Robust native fish populations in $\mathrm{Ha}-$ waiian streams may potentially exert "topdown" control over algal standing biomass, resulting in lowered densities. Because this topic has not yet been studied, it is an important area for future research.

Although not addressed in the scope of this study, flood disturbance occurring in Hanakāpī'ai and Limahuli Streams during the study period may have influenced macroalgal species diversity and abundance. The effects of flood disturbance on these attributes can be substantial (e.g., Grimm and Fisher 1989), and community interactions in recovery processes can be complex depending upon the resistance and resilience of individual species to disturbance events (Peterson 1996). During the study period, Hanakāpi'ai Stream had nearly twice the discharge of Limahuli Stream, and data obtained from a permanent U.S. Geological Survey flow gauge on lower 
Limahuli Stream (station 1611400, $27.4 \mathrm{~m}$ [90 ft] elevation) indicated that flood flow (three times annual mean flow) occurred 23 times. It was presumed that shared rainfall regimes in the region generated similar flood profiles in the two streams and thus that sampling at similar times and locations would yield valid between-stream comparisons on spatial scales. Because of the central role played by macroalgal species in supporting stream food webs, understanding their responses to flow variation and disturbance on temporal scales is an essential area of future research. This is especially true in light of the emphasis currently being placed by regulatory agencies in Hawai'i on developing meaningful instream flow standards.

Less than $10 \%$ of Hawai'i's 376 identified perennially flowing streams have been sampled for algae, and only a handful have been inventoried to the watershed scale achieved in this study. Based on our results, we believe that the numbers of macroalgal species in freshwater habitats in the Hawaiian Islands have been grossly underestimated, as has the potential level of endemicity. Therefore, continued surveys on regional scales building on methodologies presented in this study are essential to adequately assess the true diversity and uniqueness of Hawai'i's freshwater algal flora.

\section{ACKNOWLEDGMENTS}

This paper is dedicated to the memory of Charles W. McDonald, who was instrumental in collecting the field data for this study.

\section{Literature Cited}

Collins, F. S. 1908-1918. The green algae of North America. Bibl. Phycol. 11:1-450.

Couret, C. L., Jr. 1976. The biology and taxonomy of a freshwater shrimp, Atya bisulcata Randall, endemic to the Hawaiian islands. M.S. thesis, University of Hawai' $i$ at Mānoa, Honolulu.

Cummins, K. W. 1962. An evaluation of some techniques for the collection and analysis of benthic samples with special emphasis on lotic waters. Am. Midl. Nat. 67:477-504.

Desikachary, T. V. 1959. Cyanophyta. Indian Council of Agricultural Research, New Delhi.

Grimm, N. B., and S. G. Fisher. 1989. Stability of periphyton and macroinvertebrates to disturbance by flash floods in a desert stream. J. North Am. Benthol. Soc. 8:293-307.

Hambrook, J. A., and R. G. Sheath. 1991. Reproductive ecology of the freshwater red alga Batrachospermum boryanum Sirodot in a temperate headwater stream. Hydrobiologia 218:233-246.

Hardy, D. E. 1960. Insects of Hawaii. Vol. 10. Diptera-Brachycera. University of $\mathrm{Ha}$ wai'i Press, Honolulu.

Hill, W. R., and B. C. Harvey. 1990. Periphyton responses to higher trophic levels and light in a shaded stream. Can. J. Fish. Aquat. Sci. 12:2307-2314.

Hill, W. R., M. G. Ryon, and E. M. Schilling. 1995. Light limitation in a stream ecosystem: Responses by primary producers and consumers. Ecology 76:1297-1309.

Hustedt, F. T. 1942. Sußwasser-Diatomeen des Indomalayischen Archipels und der Hawaii-Inseln. Int. Rev. Gesamten Hydrobiol. Hydrogr. 42:1-252.

Kido, M. H. 1996. Morphological variation in feeding traits of native Hawaiian stream fishes. Pac. Sci. 50:184-193.

—. 1997a. Feeding strategies and web dynamics of coexisting native Hawaiian stream gobies (Gobiidae). Micronesica 30: 71-82.

- 1997b. Food relations between coexisting native Hawaiian stream fishes. Environ. Biol. Fishes 49:481-494.

Kido, M. H., P. Ha, and R. A. Kinzie III. 1993. Insect introductions and diet changes in an endemic Hawaiian amphidromous goby, Awaous stamineus (Pisces: Gobiidae). Pac. Sci. 47:43-50.

Kido, M. H., D. E. Heacock, and A. Asquith. 1999. Alien rainbow trout (Oncorbynchus mykiss) (Salmoniformes: Salmonidae) diet in Hawaiian streams. Pac. Sci. 53:242251.

Lemmerman, E. 1905. Die Algenflora der 
Sandwich-Inseln. Ergebnisse einer Reise nach dem Pacific. H. Schauinsland 1896/ 97. Engler's Bot. Jahrb. 34:607-632.

MacCaughey, V. 1918a. Algae of the Hawaiian Archipelago. I. Bot. Gaz. 65:42-57. 1918b. Algae of the Hawaiian Archipelago. II. Bot. Gaz. 65:121-149.

Nordstedt, C. F. O. 1876. De algae aquae dulcis et de characeis ex insulis Sandvicensibus a Sv. Berggren 1875 reportatis. Minesskr. Fys. Sallsk. Lund 7:1-24.

Peterson, C. G. 1996. Response of benthic algal communities to natural physical disturbance. Pages 375-402 in R. J. Stevenson, M. L. Bothwell, and R. L. Lowe, eds. Algal ecology: Freshwater benthic ecosystems. Academic Press, New York.

Prescott, G. W. 1962. Algae of the western Great Lakes area (with an illustrated key to the genera of desmids and diatoms). W. C. Brown Publishers, Dubuque, Iowa.

Richardson, K., J. Beardall, and J. A. Raven. 1983. Adaptation of unicellular algae to irradiance: An analysis of strategies. New Phytol. 93:157-191.

SAS Institute. 1989. SAS/STAT user's guide, version 6. 4th ed. 2 vols. SAS Institute, Cary, North Carolina.

Sheath, R. G., and K. M. Cole. 1992. Bio- geography of stream macroalgae in North America. J. Phycol. 28:448-460.

Sherwood, A. R., M. H. Kido, and C. W. Morden. 2002. New records of freshwater macroalgae from the Hawaiian Islands. 1. Chlorophyta. Rec. Hawaii Biol. Surv. (in press).

Smith, G. M. 1950. The fresh-water algae of the United States. McGraw-Hill, New York.

Surber, E. W. 1937. Rainbow trout and bottom fauna production in one mile of stream. Trans. Am. Fish. Soc. 66:193-202.

Tilden, J. E. 1901. Collection of algae from the Hawaiian islands. [Thrum's] Hawaii. Annu. 1901:106-113.

Vis, M. L., R. G. Sheath, J. A. Hambrook, and K. M. Cole. 1994. Stream macroalgae of the Hawaiian Islands: A preliminary study. Pac. Sci. 48:175-187.

Wagner, W. L., and V. A. Funk. 1995. Preface. Pages ix-xi in W. L. Wagner and V. A. Funk, eds. Hawaiian biogeography: Evolution on a hot spot archipelago. Smithsonian Institution Press, Washington.

Williams, F. X. 1939. Biological studies of Hawaiian water-loving insects, Part IIIDiptera. Proc. Hawaii. Entomol. Soc. 10:281-315. 